\title{
SOME NEW SPECIES OF ROBBER FLIES
}

\section{(DIPTERA : ASILIDAE)}

\author{
By FRANK M. HULL \\ University of Mississippi
}

Recent studies of Diptera have brought to light several undescribed species of Asilidae, which are here described.

Laphystia torpida, new species

A stout species of medium size. The abdominal pattern is superficially like that of Laphystia annulata, new species, but the femora and tibiae are chiefly black. Length $10 \mathrm{~mm}$.

Female. Head: The head is black, the face is covered with dense, pale, yellowish grey, nearly white, fine micropubescence. Similar cover is found on the front, vertex and upper occiput. The pollen of the lower occiput is more nearly white and its pile fine, rather dense and whitish. There is a cluster of 6 or 7 weak, yellowish white bristles on the upper fourth of the occiput on each side. The low but wide ocellarium bears numerous, erect, stiff, yellowish hairs which are confined chiefly to the side slopes. Proboscis and antenna black, the former not quite extended as far as the face and robust, obtuse, with medial ridge, slightly swollen base and scattered, long, yellowish white hairs at the base below and a rather dense tuft of similar hairs at the apex. The black of antenna is covered by a pale, yellowish grey or nearly white pubescence of microscopic character and the first segment bears a slender, whitish bristle and abundant, whitish pile. Thorax: The thorax is black, upper pleuron and the lateral mesonotum are densely covered with pale, brownish yellow pollen, becoming more greyish white ventrally on the pleuron. There is much coarse, yellowish white, long, stiffened hairs on the posterior half and upper border of the mesopleuron and the anterior sternopleuron, besides more scanty pile on the pteropleuron and posterior hypopleuron. There is a broad, vertical band of slender, long, bristly, pale hairs on the 
metapleuron. Middle of mesonotum densely pollinose and slightly more brownish and still pale. Before and after the suture on each side there is a short, narrow, more or less bare stripe which may be natural or worn. Posterior margin of scutellum also bare and black. The disc densely pale pollinose with abundant, coarse, appressed, pale yellowish pile and similar pile in front of the scutellum. On the greater part of the mesonotum the pile is scanty, minute, flat appressed and golden. Down the middle anterior area is a slightly darker, greyish brown vitta, which is divided by a pale, narrow stripe. Legs: The legs are black, largely pale grey pollinose, the pile short, coarse, appressed, brassy and glittering. The bristles are weak, yellowish white and moderately numerous and short, except on the anterior and middle tibiae where they make long, spike-like, regularly spaced fringes. The extreme base of the anterior and middle femora and slightly more of the hind femoral base light reddish brown. All the tibiae narrowly and obscurely light brown at base. All the tarsi quite dark brown. Hind femur with 6 lateral bristles, 4 or 5 ventrolateral bristles and some ventromedial, bristly hairs and broadly covered ventrally with abundant, fine, short, erect, pale pile continued on to the ventral surface of the hind tibia. Hind tibia with moderately long bristles: 4 dorsolateral and 4 ventrolateral elements, their basitarsi robust. Middle femur with 1 long, anterior and 1 short anteroventral bristle, each close to the middle, 1 short, posterior bristle near the apex and 5 or 6 long, slender, basal and ventral bristles and numerous bristly hairs on the ventral surface. Middle tibia with 3 anteroventral bristles, 3 anterodorsal, 4 posterodorsal, 4 long, slender, posteroventral hairs and 4 conspicuous, long, evenly spaced, ventral bristles. Anterior femur with a slender, short bristle anterodorsally near the apex, the ventral compliment similar to the middle pair and no other bristles. Anterior tibia similar to the middle tibia and the conspicuous fringe in this case consists of 5 long, posteroventral bristles. Claws slender, uniformly and gently curved from the base, sharp. Pulvilli on all legs reduced to less than half the length of the claws. Empodium long and 
flattened. Wings: The wings are greyish hyaline. There is a minute stub near the base of the anterior branch of the third vein. First posterior cell a little narrowed, marginal cell widely open, fourth posterior cell and anal cell each closed with a long stalk. Alula well developed, ending at the apex of the anal cell. Alula large. Abdomen: The abdomen is black, dully shining, wider than the thorax, widest on the third segment, the posterior third of each tergite or a little less is densely clay colored pollinose and nearly the same shade as the mesonotum. The pollen extends completely and widely over all the lateral margins except for a narrow triangle at the base of the second segment. Pile scanty, flat appressed and brassy. Sides of first tergite with a patch of weak, yellow bristles and other pile. Middles of lateral margins of second tergite with a transverse row of 7 or 8 short and more stout, pale bristles. Third tergite with 5 such bristles; fourth with 4 , fifth and sixth tergites with 2 such bristles. The minute ninth segment is dull black; seventh and eighth segments quite short.

Type. Female; Tracy, California, San Jouquin County, June 13, 1949, J. W. McSwain collector. Type in the collection of the University of California.

Laphystia annulata, new species

A small species which traces to Laphystia confusa. It is characterized by the dense, silvery grey pollen, the black antenna, the pale yellow femora and tibiae, the latter being quite narrowly black at the apex. Length $9 \mathrm{~mm}$.

Male. Head: The head is black, everywhere silvery white pollinose with long, dense, silvery white, fine hairs on face, front, occiput, vertex and ocellarium. Upper corners of the vertex with 6 or 7 white bristles on each side. Proboscis shining black. Antenna black, its pile white. Thorax: The thorax is black, densely greyish pollinose on the pleuron, changing on the upper mesopleuron to a faint yellowish hue. Pollen of mesonotum faintly yellowish, the pile minute, appressed and pale brassy yellow, except for a collar of nearly erect, longer, 
white hairs anteriorly between the humeri. Bristles of lateral margins yellowish white and weak; 2 on notopleuron, 4 above wing, 2 on post callus and the scutellar margin with 4 pairs of slender hairs. Legs: The whole of the femora and all of tibiae except extreme apex and the extreme base of the basitarsi yellowish. Remaining tarsi blackish. Pile appressed and white or yellowish white. Bristles weak, short, except on the anterior and middle tibia, few in number and of the same color as the pile. Claws fine, sharp, black with the basal third yellowish. Pulvilli pale, thin, well developed. Wings: The wings are nearly hyaline, the second vein and the third vein on the basal part yellow, other veins light brown. Marginal cell open though narrowly. Abdomen: The abdomen is shining black. All of the first segment except the narrow posterior margins greyish white pollinose. Similar pollen covers approximately one-half of the second and third segments, being slightly decreased submedially and slightly increased in the middle and laterally widely covering the whole lateral margin. On the fourth and fifth and sixth segments a little less than half of the segments are covered by this band. Also the posterior margin of the second and fifth segments narrowly black except laterally. Pile appressed, setate, short and reddish yellow on the black portions, shining white on the pollinose portions. Terminalia short and black with white pile.

Female similar to the male.

Type. Male; near Navajo, Arizona, July 11, 1954, F. M. Hull collector. Allotype, female, 9 paratype males, 2 paratype females, all with the same data. In the collection of the author.

Laphystia annulata interrupta, new subspecies

Similar to Laphystia annulata, new species but with the grey bands on the abdomen distinctly interrupted, each half attenuate so that also more of the posterior margin is shining black.

Type. Female; near Navajo, Arizona, July 11, 1954, F. M. Hull collector. In the collection of the author. 
Laphystia rubra, new species

A small species distinguished by the uniformly shining, dark red abdomen and the almost entirely brownish yellow femora. Length $8 \mathrm{~mm}$.

Female. Head: The head is black. Face laterally with silvery, minute, appressed pubescence, brownish yellow in the middle on the upper half; the mystax consists of 2 or 3 rows of short, stout, brownish yellow bristles above the epistoma. There are a few fine, white hairs on the upper part of the face laterally which are not very long and appressed. First 2 segments of antenna black, the third brownish black, the first segment with 2 long and 1 short, stout, brownish yellow bristle below. Front in the middle with pale brownish yellow pollen, the sides more whitish. Upper front and medial part of the vertex adjacent to the eye with a few, short, stiff, brownish yellow setae. Occiput with fine pile except above, where there are 7 pairs of slender, reddish yellow bristles. Thorax: The thorax is black, pleuron thinly dusted with yellowish white pollen and a few long, yellowish hairs on the mesopleuron. Metapleuron with a vertical row of 12 quite slender, pale yellowish hairs and a few other short hairs. Mesonotum with abundant, minute, flat appressed yellow setae. Bristles brownish yellow, 2 on notopleuron, one of which is quite small, 2 above wing, 2 on post callus, 1 of them small, and scutellar margin with only a few minute, upturned setae. Scutellar disc likewise with a few appressed, brownish golden, minute setae directed outward. Knob of halteres yellow, the base reddish brown. Legs: The femora are brownish orange with an obscure, dark streak on the dorsal surface of the hind femur confined to the outer half. A smaller, distal, dorsal, obscure, dark patch on the anterior femur and a trace of such color distally on the middle femur. Apical fourth of all tibiae obscurely brownish black. All tarsi quite dark brown. Pile of legs minute, appressed, pale brownish yellow and setate. Bristles weak, pale and few in number. There is a whitish bristle ventrally near the base of the hind femur and sometimes a second smaller bristle a little beyond it. Each femur has near the apex 
a small posterior or medial bristle. Each femur has a still smaller yellow bristle laterally near the apex. Claws slender, black, with the base reddish. Pulvilli slender, long and whitish. Wings: The wings are nearly hyaline, the second vein and the basal part of the third vein pale brown, other veins light brown. Marginal cell open narrowly. Abdomen: The abdomen is more robust than in Laphystia annulata, new species. Tergites dark, shining, brownish red with the whole lateral margins only pale brownish yellow pollinose. This pollen extends narrowly along the posterior margin of the sixth tergite but leaves the middle interrupted and bare. The short seventh and eighth tergites entirely pollinose. Pile over the middles of the tergites minute, flat appressed and reddish yellow. Side margins of first segment with 4 stout, reddish bristles and the second and third segments with 4, the fourth segment with 3 and the fifth and sixth segments each with 2 similarly colored bristles.

Type. Female; near Navajo, Arizona, July 11, 1954. Paratype female, same data. F. M. Hull collector. In the collection of the author. 

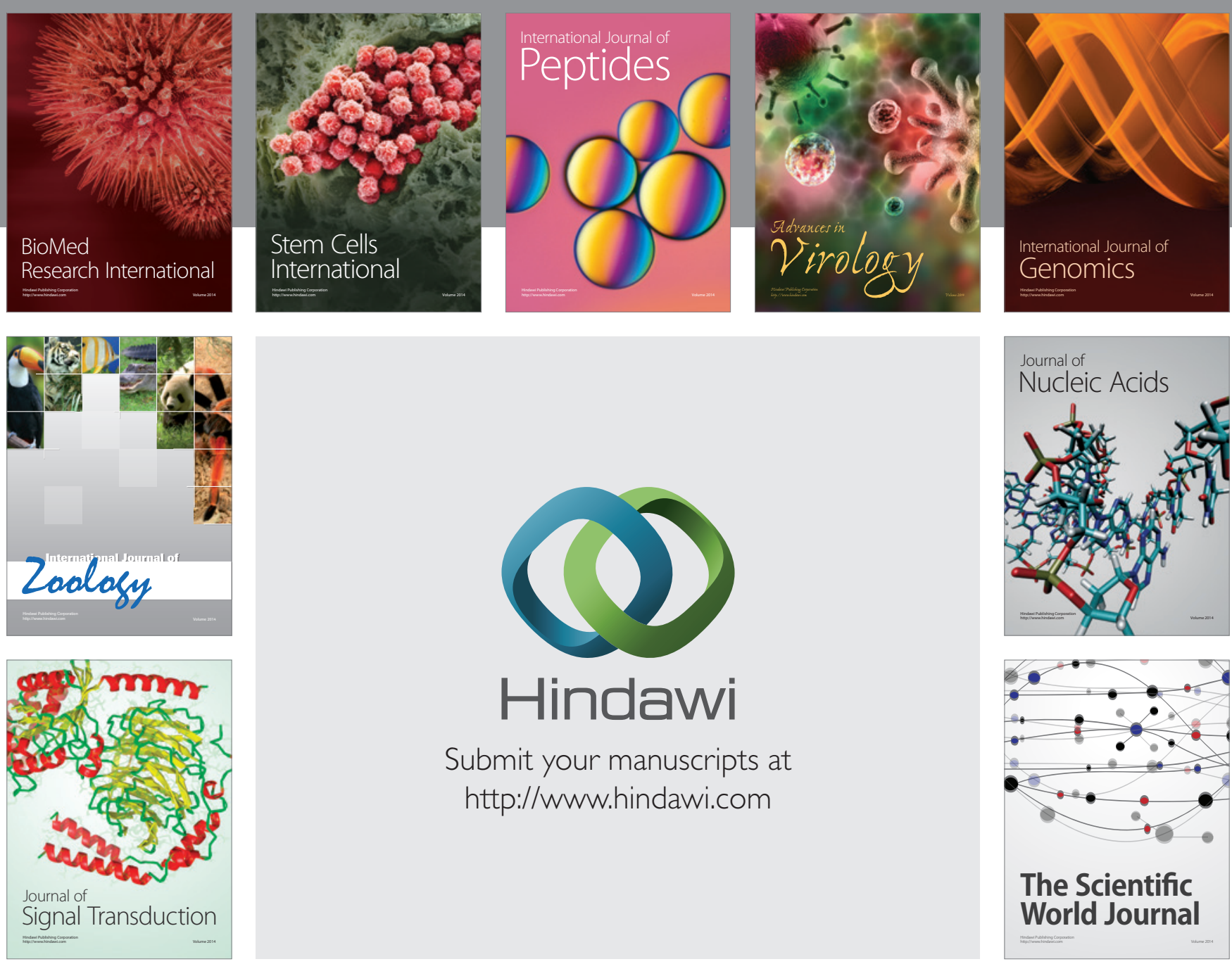

Submit your manuscripts at

http://www.hindawi.com
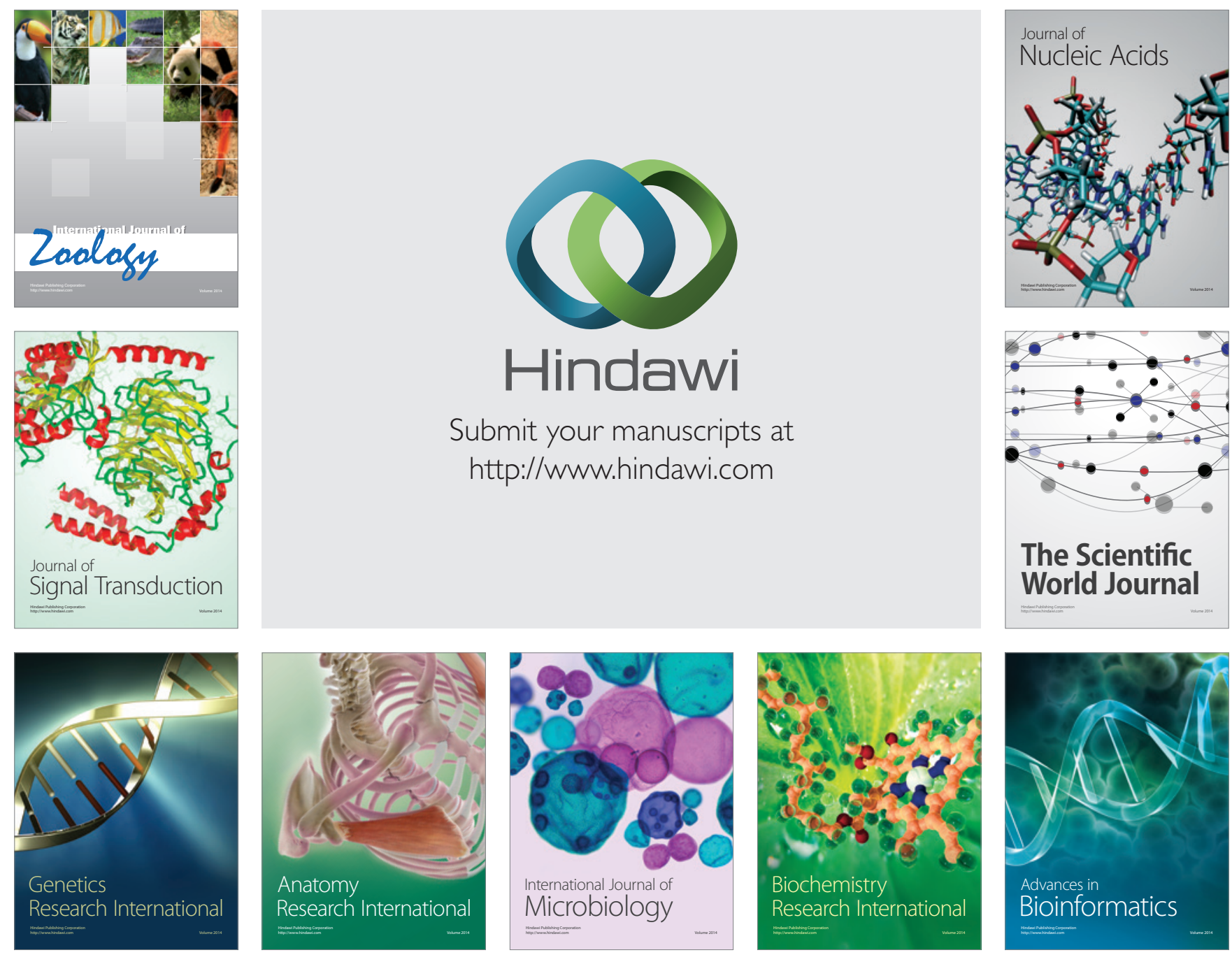

The Scientific World Journal
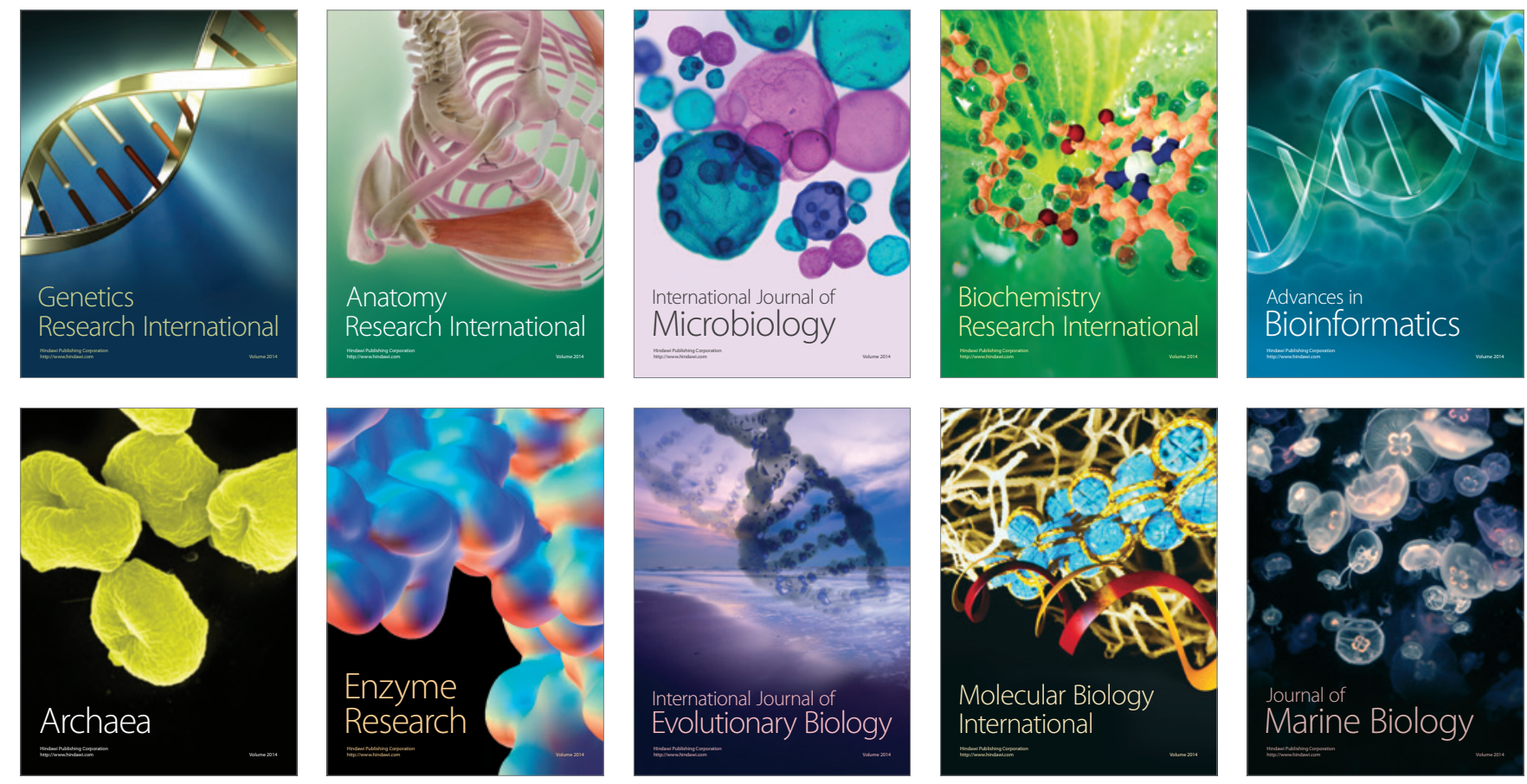